\title{
Dominant negative knockout of p53 abolishes ErbB2-dependent apoptosis and permits growth acceleration in human breast cancer cells
}

\author{
GC Huang', S Hobbs'², M Walton² and RJ Epstein*,3,4 \\ 'Department of Medicine, King's College School of Medicine, Bessemer Rd, London, SW3, UK; ${ }^{2}$ CRC Centre for Cancer Therapeutics, Institute of Cancer \\ Research, Cotswold Rd, Sutton SM2 5NG, Surrey, UK; ${ }^{3}$ Department of Metabolic Medicine, Imperial College School of Medicine, Du Cane Rd, London \\ WI 2 ONN, UK; ${ }^{4}$ Division of Medical Sciences, National Cancer Centre, Hospital Drive, Singapore 169610
}

\begin{abstract}
We previously reported that the ErbB2 oncoprotein prolongs and amplifies growth factor signalling by impairing liganddependent downregulation of hetero-oligomerised epidermal growth factor receptors. Here we show that treatment of A43I cells with different epidermal growth factor receptor ligands can cause growth inhibition to an extent paralleling ErbB2 tyrosine phosphorylation. To determine whether such growth inhibition signifies an interaction between the cell cycle machinery and ErbB2-dependent alterations of cell signalling kinetics, we used MCF7 breast cancer cells (which express wild-type p53) to create transient and stable ErbB2 transfectants (MCF7-B2). Compared with parental cells, MCF7-B2 cells are characterised by upregulation of $\mathrm{p} 53, \mathrm{p} 2 \mathrm{I}^{\text {WAF }}$ and $\mathrm{Myc}$, downregulation of $\mathrm{BCl}$, and apoptosis. In contrast, MCF7-B2 cells co-transfected with dominant negative p53 (MCF7-B2/Lp53) exhibit reduced apoptosis and enhanced growth relative to both parental MCF7-B2 and control cells. These data imply that wild-type p53 limits survival of ErbB2-overexpressing breast cancer cells, and suggest that signals of varying length and/or intensity may evoke different cell outcomes depending upon the integrity of cell cycle control genes. We submit that acquisition of cell cycle control defects may play a permissive role in ErbB2 upregulation, and that the ErbB2 overexpression phenotype may in turn select for the survival of cells with p53 mutations or other tumour suppressor gene defects.
\end{abstract}

British Journal of Cancer (2002) 86, I I04- | 109. DOI: 10.1038/sj/bjc/6600219 www.bjcancer.com

(C) 2002 Cancer Research UK

Keywords: ErbB2; p53; apoptosis

The molecular pathways controlling cell growth and death are deeply intertwined, with gene products as diverse as Myc (Evan et al, 1992; Harrington et al, 1994; Barone and Courtneidge, 1995; Packham et al, 1996; Kauffmann-Zeh et al, 1997), Raf (Morrison et al, 1989; Pumiglia and Decker, 1997; Woods et al, 1997) and MAP kinase (Traverse et al, 1992; Ben-Levy et al, 1994; Marshall, 1995; Marte et al, 1995; Kimura et al, 1999) being firmly implicated in both outcomes. By the same token, well-characterised mitogens such as the epidermal growth factor receptor (EGFR) and the ErbB2 (HER2/neu) oncoprotein have been causally linked to cell growth inhibition and apoptosis (Gill and Lazar, 1981; Kawamoto et al, 1984; Filmus et al, 1985; Polet, 1990; Tagliabue et al, 1991; Armstrong et al, 1994; Harris et al, 1995; Kita et al, 1996). Since these molecules are often overexpressed in human breast tumours (Sainsbury et al, 1985; Slamon et al, 1989) subtypes of which exhibit prominent apoptosis (Bodis et al, 1996; Liu et al, 1992) - a better understanding of their pathogenetic significance could be relevant to anticancer drug development.

*Correspondence: RJ Epstein, Laboratory of Tumour Phosphoproteomics, Division of Medical Sciences, National Cancer Centre, I I Hospital Drive, Singapore 1696I0; E-mail: daarje@nccs.com.sg

Received 3 January 2002; accepted 24 January 2002
We previously reported that growth arrest of 3T3 cells is associated with catalytic activation of ErbB2 (Epstein et al, 1990), and more recently demonstrated that ErbB2 lengthens and intensifies mitogenic signalling by impairing ligand-dependent EGFR downregulation (Huang et al, 1999). In addition, we have shown that the functionally distinct EGFR ligands, EGF and transforming growth factor-alpha (TGF $\alpha$ ), exert differing effects on EGFR downregulation and hence on the duration of ErbB2 co-activation: high concentrations of EGF initially cause prolonged EGFR activation associated with ErbB2 heterodimerisation, followed by eventual EGFR downregulation and signal cessation; whereas TGF $\alpha$ fails to downregulate EGFR, leading to sustained signalling (Gulliford et al, 1997; Ouyang et al, 1999a). The possibility is thus raised that ErbB2 could mimic the tumorigenic effects of TGF $\alpha$ in cancer cells by its similar ability to prolong EGFR signalling.

The above-mentioned differential induction of growth stimulation or inhibition by EGFR (Filmus et al, 1985; Polet, 1990; Armstrong et al, 1994; Gulli et al, 1996) and ErbB2 (Tagliabue et al, 1991; Harris et al, 1995; Kita et al, 1996) strongly suggests an interaction between downstream signal duration (e.g. of MAP kinase) and cell cycle control proteins (Traverse et al, 1992; Marshall, 1995). To address the possibility that ErbB2-dependent changes in signal duration may contribute to such differences in cell fate, it is necessary to create cell systems in which the effects of ErbB2 expression can be correlated with the function or 
dysfunction of a given cell cycle regulatory molecule. Here we show that the effects of ErbB2 on cell signalling kinetics are selectively associated with induction of apoptosis in oestrogenresponsive MCF7 human breast cancer cells - which, like most hormone-sensitive cancers (Caleffi et al, 1994; Elledge et al, 1995; Berns et al, 2000), express wild-type p53 (Casey et al, 1991; Balcer-Kubiczek et al, 1995; Furuwatari et al, 1998) but normally do not overexpress ErbB2 (Wright et al, 1997; FerreroPous et al, 2000; Pinto et al, 2001). Dominant negative knockout of p53 converts growth inhibition to growth enhancement in these ErbB2-transfected cells, suggesting that a p53 mutational pathway could favour selection for ErbB2 gene amplification during tumour progression.

\section{MATERIALS AND METHODS}

\section{Cell lines, reagents, antibodies, and immunoblotting}

MCF7 and A431 cells were obtained from the American Type Culture Collection (Rockville, MD, USA). Synthetic human EGF and TGF $\alpha$ were purchased from Sigma. Activation-state-specific EGFR antibodies, and antibodies to $\mathrm{p} 53, \mathrm{Myc}, \mathrm{Bcl} 2$ and $\mathrm{p} 21^{W A F}$, were purchased from Cambridge BioScience (Cambridge, UK). Polyclonal antibodies to $\mathrm{Tyr}^{1248}$ - and $\mathrm{Tyr}^{1222}$-phosphorylated ErbB2 were developed and validated for receptor-specificity as described previously (Epstein et al, 1992; Ouyang et al, 1998). For immunoblotting studies, cells were lysed as previously described (Gulliford et al, 1997): protein lysates were immediately boiled for $5 \mathrm{~min}$ in sample buffer $(6.7 \%$ sodium dodecyl sulfate, $30 \%$ glycerol, $62.5 \mathrm{~mm}$ Tris base $\mathrm{pH} 6.8,0.01 \%$ bromophenol blue) then loaded onto a $7.5 \%$ SDS-polyacrylamide gel. Samples were electrophoresed and transblotted onto nitrocellulose as described (Towbin et al, 1979).

\section{Growth curves and apoptosis assays}

Cell growth was measured using a multiwell colorimetric assay based on sulphorhodamine B (SRB) spectrophotometric detection. Confirmation and quantification of morphologic apoptosis was performed using a Tdt-mediated dUTP nick-end labelling (TUNEL) kit to directly detect DNA fragmentation in situ. Briefly, cells were plated and grown on glass slides, treated with ligand for the required period, then fixed in $4 \%$ paraformaldehyde for $30 \mathrm{~min}$ at room temperature. The slides were washed with PBS three times, after which the cells were permeabilised with $0.1 \%$ Triton-X-100 in $0.1 \%$ sodium citrate for $10 \mathrm{~min}$. After washing, the cells were covered in $50 \mu \mathrm{l}$ of equilibration solution for $10 \mathrm{~min}$, then covered with $50 \mu \mathrm{l}$ of labelling solution (Biovation) and incubated at $37^{\circ} \mathrm{C}$ for $1 \mathrm{~h}$ while light-protected. The slides were then washed, covered in $10 \mu \mathrm{l}$ counterstain for $10 \mathrm{~min}$, and analysed using fluorescence microscopy.

\section{Cell transfection}

For calcium phosphate transfection, cells were seeded in $90 \mathrm{~mm}$ diameter cell culture dishes at $5 \times 10^{5}$ cells $\mathrm{ml}^{-1} 24 \mathrm{~h}$ before the transfection. One plate was required for each transfection experiment; the monolayer normally grew to $80 \%$ confluence by the following day, and the medium was changed $3 \mathrm{~h}$ before the transfection. Two sterile microfuge tubes were labelled for each transfection experiment: to one tube was added $500 \mu \mathrm{l}$ of $2 \times \mathrm{BBS}(\mathrm{pH} 6.95)$ and to the other tube was added $125 \mu \mathrm{l}$ of $1 \mathrm{M} \mathrm{CaCl}, 10-20 \mu \mathrm{g}$ of recombinant plasmid DNA which contained the relevant cDNA; distilled $\mathrm{H}_{2} \mathrm{O}$ was added to give a final volume of $500 \mu \mathrm{l}$. This was added to equal the volume of $2 \times$ concentrated $\mathrm{BBS}$ using a sterile Pasteur pipette. At the same time, filtered air was passed through the $2 \times$ BBS buffer $(\mathrm{pH}$ 6.95) with a second Pasteur pipette, and the DNA mixture was then incubated at room temperature for $20 \mathrm{~min}$ to allow precipitation. The $\mathrm{DNA} / \mathrm{CaPO}_{4}$ precipitate was mixed by inverting the tube, and was added directly to a $10 \mathrm{ml}$ cultured cell dish dropwise with gentle shaking, and the cell culture incubated at $37^{\circ} \mathrm{C}$ with $3 \%$ $\mathrm{CO}_{2}$ overnight followed by washing with PBS and re-culturing in fresh medium at $37^{\circ} \mathrm{C}$ with $5 \% \mathrm{CO}_{2}$.

\section{Constructs and selection procedures}

The well-characterised temperature-sensitive dominant negative p53 construct (Kuerbitz et al, 1992; Slichenmeyer et al, 1993; Zhang et al, 1994; Vasey et al, 1996) was kindly provided by Dr B Vogelstein (Baker et al, 1990). For selection, transfected cells were plated at $5 \times 10^{4}$ cells $/ 9 \mathrm{~cm}$ tissue culture dish with relevant reagents: dominant negative p53 was selected with neomycin. The wild-type ErbB2 construct, which is under the control of the Moloney murine leukaemia virus LTR and contains the Ecogpt selectable marker from E. coli (Di Fiore et al, 1987), was selected with HAT (hypoxanthine, aminopterin and thymidine) as described by Mulligan and Berg (1981). For double transfection a pool of six p53 dominant negative clones $(\Delta \mathrm{p} 53)$ or $\mathrm{p} 53$ empty vector clones were transfected with either ErbB2 or ErbB2 empty vector, and selected with HAT medium for at least 6 weeks. Resistant colonies were cloned and a pool of six clones was cultured with HAT medium to amplify the cell number. For analysis, the cells were cultured in normal medium for at least 2 weeks before the experiments were performed. For morphologic analysis, cells were grown in plastic 8chamber containers (LabTek; Gibco) and the monolayers photographed using a Zeiss microscope. Growth experiments were carried out in 96-well plates using quantification of Hoechst dye immunofluorescence in six matched samples following 3 days growth to assess cumulative DNA content.

\section{RESULTS}

Consistent with earlier reports (Gill and Lazar, 1981; Polet, 1990), ligand stimulation experiments confirm EGF-dependent growth inhibition of sparsely-plated A431 cells (Figure 1A, upper panel). The extent of growth inhibition correlates with the intensity of equimolar ligand-dependent ErbB2 tyrosine phosphorylation as detected by site-specific phosphoantibodies (Ouyang et al, 1998) which confirm greater ErbB2 tyrosine phosphorylation following EGF stimulation (Figure 1A, lower panel). As reported previously, this initial difference in ligand-dependent signal intensity is maintained and further exaggerated over the subsequent $12 \mathrm{~h}$ (Ouyang et al, 1999a). Correlation of light microscopy with TUNEL assay indicates that the growth-inhibitory effects of EGF in this context are associated with increased apoptosis (Figure 1B).

The foregoing data do not distinguish whether the observed growth inhibition is induced by ligand-dependent ErbB2 co-activation per se or, alternatively, by the downstream consequences of growth factor signal prolongation induced by ligand-dependent ErbB2 heterodimerisation. However, since our previous work documented a marked prolongation of EGFR signalling by ErbB2 expression (Huang et al, 1999), we elected to test the latter hypothesis by creating ErbB2 transfectants in cell lines differing solely in terms of cell cycle control functionality. To this end, MCF7 human breast cancer cells known to express both copies of the wild-type p53 gene (Casey et al, 1991; Balcer-Kubiczek et al, 1995; Furuwatari et al, 1998) were transiently transfected with ErbB2. As shown in Figure 2A, ErbB2 expression in these cells induces increased immunoreactivity of both activated ErbB2 and EGFR, consistent with previous studies (Huang et al, 1998, 1999), while also inducing increased expression of p53, p $21^{\text {WAF }}$ and Myc. Of note, ErbB2 expression is associated with reduced $B c l 2$ expression - an effect reported previously following primary overexpression of p53 (Haldar et al, 1994). These effects on protein expression are accompanied by morphologic changes (membrane blebbing, chromatin 

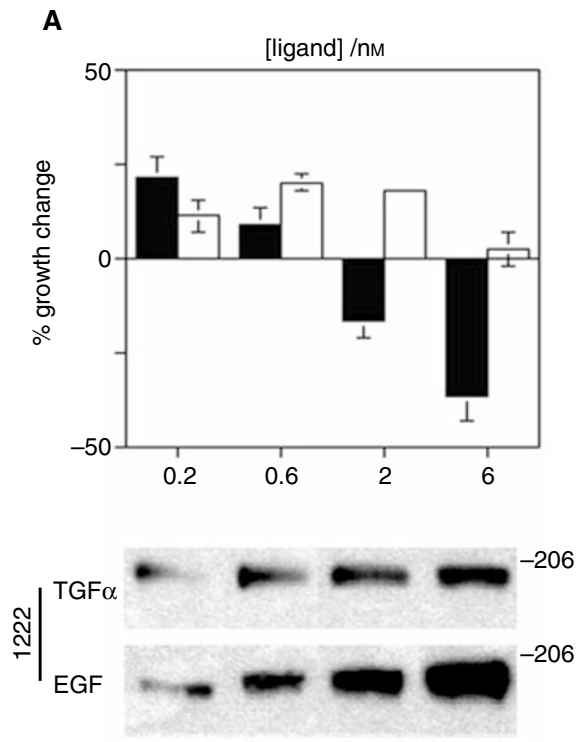

B

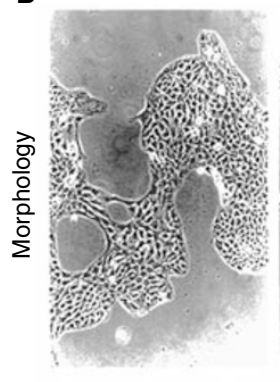

Control
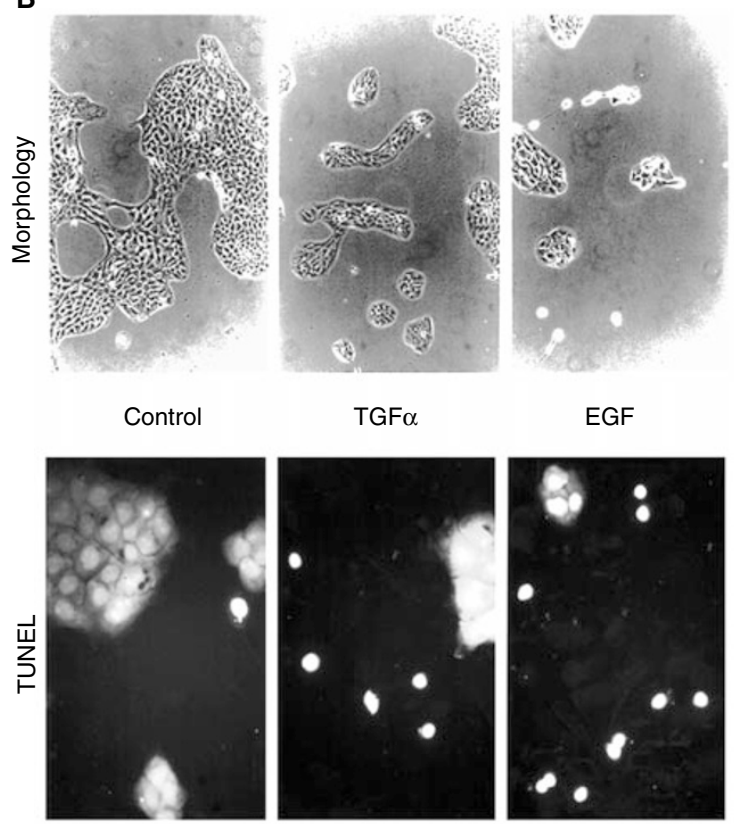

TGF $\alpha$
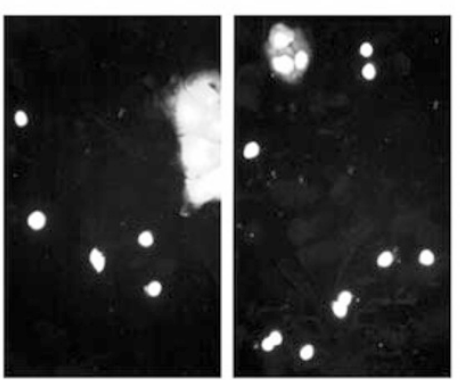

Figure I Relative effects of EGF and TGF $\alpha$ on cell growth, growth inhibition, and ErbB2 tyrosine phosphorylation of A43 I cells. (A) Effects of dif ferential ligand treatment on cell growth, relative to growth of untreated controls (upper figure) and to ligand-dependent ErbB2 tyrosine phosphorylation (lower figure). In the upper figure, cells were plated at $1.5 \times 10^{4} \mathrm{ml}^{-1}$ seeding density and stimulated for 6 days with the respective ligand (EGF, solid columns; TGF $\alpha$, open columns) prior to counting using a sulphorhodamine-based assay as described. Nanomolar ligand concentrations are represented on the abscissa. The results are expressed as a percentage change relative to control cell growth; error bars are based on six measurements. The lower figure shows the corresponding short-term effects of EGF and TGF $\alpha$ on ErbB2 $Y^{1222}$ phosphorylation: cells were treated for 5 min with EGF or TGF $\alpha$ at the indicated nanomolar concentration prior to lysis, electrophoresis and immunoblotting using $\mathrm{APY}^{1222}$. The bands were visualised using ECL. (B) Visualisation of cell death by light microscopy and TUNEL assay (see Materials and Methods) associated with ligand treatment. Twenty-four hours following attachment, cells were treated with the respective ligands (2 nM) in serum-free medium. Typical low-power views of triplicate plates are shown after $48 \mathrm{~h}$ treatment using light microscopy (above) and fluorescence microscopy (below).
A
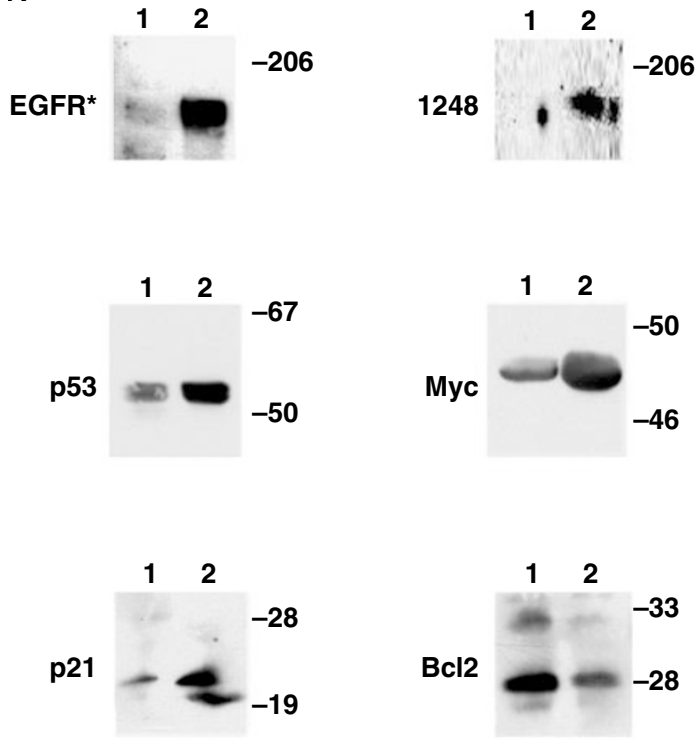

B
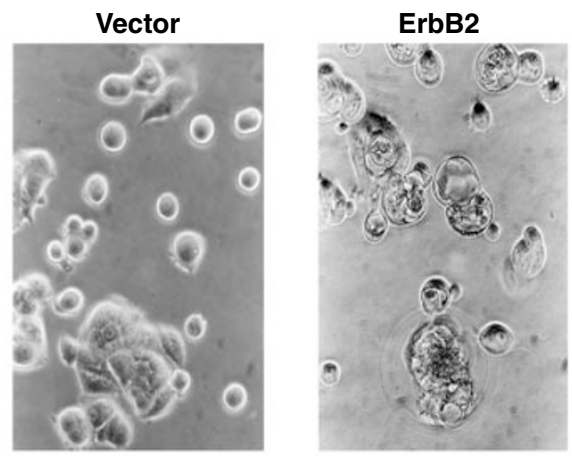

Figure 2 Effects of transient ErbB2 transfection on parental MCF7 cells. (A) Effects of ErbB2 transfection on protein expression. Control (lane I; vector-only) and ErbB2-transfected cells (lane 2) were lysed and assessed by immunoblotting. EGFR*⿻丷木 kinase-active epidermal growth factor receptor; 1248, ErbB2 tyrosine-phosphorylated at position 1248, detected by the activation-specific aPY ${ }^{1248}$ antibody (Ouyang et al, 1998). (B) Effects of ErbB2 expression on morphology and apoptosis of MCF7 human breast cancer cells assessed using light microscopy. ErbB2 transfectants (at right) were generated using a standard calcium phosphate transfection procedure followed by neomycin selection. Mock transfectants containing empty plasmids are shown at left.

condensation) typical of apoptosis in ErbB2-transfected, but not vector control, cells (Figure 2B). These ErbB2-dependent changes in protein expression and morphology directly implicate ErbB2 in the activation of an apoptotic pathway.

To clarify whether the apoptosis-triggering effect of ErbB2 might be at least partly related to its effects on signalling kinetics (i.e. as opposed to an exclusive cell-killing effect of ErbB2 kinase activity), stable MCF7 cell transfectants were created using either the wildtype ErbB2 gene, the dominant-negative p53 mutant gene, or both. As in the ErbB2 transient transfectants, stable overexpression of ErbB2 selectively induces endogenous (wild-type) p53 protein overexpression (Figure 3A, upper panel, left three lanes); as expected, 


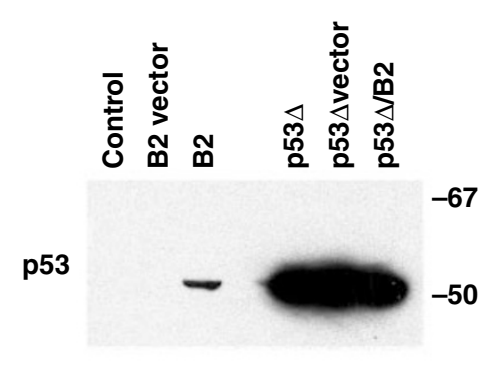

B

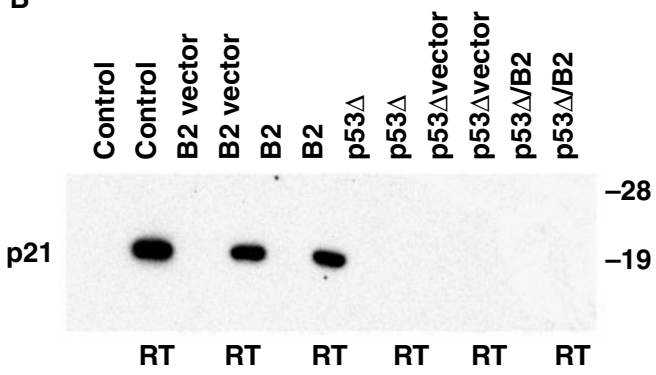

Figure 3 Effects of stable ErbB2 overexpression and/or p53 knockout on MCF7 cell protein function as measured by expression of $\mathrm{p} 53$ and $p 2 \mathrm{I}^{\text {WAF }}$ in ErbB2 and/or mutant p53 transfectants and controls. (A) p53 immunoblot. Control, parental MCF7 cells; B2 vector, MCF7 transfected with vector alone; B2, MCF7 transfected with vector containing ErbB2 CDNA; p534, MCF7 transfected with dominant negative mutant p53; p53 $\Delta$ vector, MCF7 transfected with dominant negative $\mathrm{p} 53$ and also with empty vector used for ErbB2 studies; p53 $/$ B2, MCF7 cells transfected with dominant negative mutant $\mathrm{p} 53$ and with ErbB2. B, p2 ${ }^{\mathrm{WAF}}$ immunoblot. As indicated by the legend below, cells from even-numbered lanes received radiotherapy (RT) with 0.1 Gy X-irradiation prior to lysis. Odd-numbered lanes represent the sample order described for the upper panel.

dominant-negative mutant p53 $(\Delta \mathrm{p} 53)$ cells grossly overexpress immunoreactive p53 (Figure 3A, upper panel, right three lanes). Irradiated control and ErbB2-transfected MCF7 cells exhibit a normal increase in $\mathrm{p} 21^{\text {WAF }}$ expression following $\mathrm{X}$-irradiation (Figure 3B, lower panel, left 6 lanes). In contrast, MCF7- $\Delta$ p53 cells sustain no immunodetectable rise in p21 $1^{\text {WAF }}$ levels (Figure 3B, lower panel, right 6 lanes), thus validating the functionality of the dominant-negative p53 construct used in these experiments. Of note, p21 $21^{W A F}$ was not detectably overexpressed in stable ErbB2-overexpressing cells (Figure 3B) unlike in transient transfectants (Figure 2A), raising the possibility that prolonged ErbB2 overexpression induces clonal selection.

The four transfectant cell lines of interest - parental MCF7, MCF7-B2, MCF7- $\Delta \mathrm{p} 53$, and MCF7-B2/Dp53 - were then compared with respect to morphology and growth. Unlike parental MCF7 cells which adopt a spread-out cell appearance suggesting density-dependent growth inhibition (Figure 4A, upper left), all of the other transfectants exhibit a crowded morphology. MCF7B2 cells also exhibit striking apoptosis (Figure 4A, lower left), however, a feature which is absent from both the MCF7- $\Delta \mathrm{p} 53$ and MCF7-B2/ $\Delta$ p53 cells (Figure 4A, right upper and lower panels, respectively). Cell growth as measured by Coulter counting was increased in MCF7- $\Delta \mathrm{p} 53$ cells and reduced in MCF7-B2 cells relative to parental cell growth: MCF7-B2/ $\Delta$ p53 cells exhibit more rapid growth than parental cells, though slower than MCF7- $\Delta \mathrm{p} 53$
A

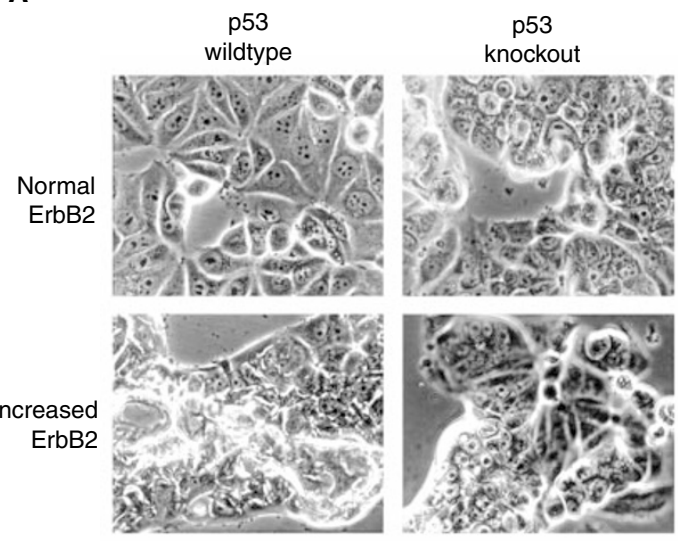

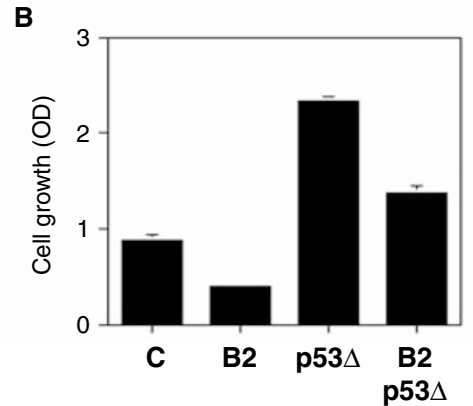

Figure 4 Effects of ErbB2 overexpression and/or p53 knockout on MCF7 cell morphology and growth. (A) Morphology of MCF7 cell variants characterised by light microscopy. Top left, parental MCF7 cells; top right, MCF7 transfected with mutant p53; lower left, MCF7 transfected with wildtype ErbB2; lower right, MCF7 co-transfected with both mutant p53 and wild-type ErbB2. (B) Cell growth of MCF7 variants following 3 days growth. Error bars represent standard errors of the mean based on six identical samples for each cell line. Abbreviations are as above.

cells (Figure 4B). Given the foregoing results, these data indicate that the observed ErbB2-dependent effects on cell fate vary with the functional status of p53, suggesting in turn that p53 may act as a sensor for ErbB2-induced changes in cell signalling kinetics.

\section{DISCUSSION}

We previously showed that ErbB2 expression causes constitutive EGF signalling by retarding downregulation of hetero-oligomerised EGFR (Huang et al, 1999). This effect most likely relates to the absence of motifs in the ErbB2 C-terminal tail for receptor internalisation and degradation (Sorkin et al, 1993; Baulida et al, 1996). Since human tumours exclusively overexpress the wild-type ErbB2 rather than the transforming point mutant (Lemoine et al, 1990), a reasonable hypothesis is that tumour cells acquire a growth advantage from wild-type ErbB2 overexpression, but that this phenotype does not represent the primary transforming event - implying the co-existence, that is, of at least one other molecular defect within the tumour cells. This hypothesis is consistent with numerous reports linking tumour cell ErbB2 overexpression and p53 dysfunction (Horak et al, 1991; Mehta et al, 1995; Li et al, 1997) and identifying poor-prognosis clinical subgroups based on concurrence of these phenotypes (Tsuda et al, 1998). Moreover, our recent documentation of differential survival outcomes in ErbB2-overexpressing breast cancers associated with different phos- 
phorylation patterns (Ouyang et al, 1999b, 2001) supports the notion of multiple signalling pathways governing tumour growth phenotypes.

Given that the p53 checkpoint prevents cell-cycle progression when activated (Casey et al, 1991; Yin et al, 1992; Wyllie et al, 1995) and that the duration of growth factor signalling influences whether cells proliferate or arrest (Traverse et al, 1992; Marshall 1995), the present study suggests a model of cell signal sensing which is differentially perturbed by ErbB2 depending upon the functional p53 status. Other studies have concluded that the main in vitro and in vivo consequences of p53 mutation on cell growth relate to enhanced proliferation rather than to reduced apoptosis (Nikiforov et al, 1996; Tyner et al, 1999). Our data suggest a more complex interpretation of p53 function as a co-variable within the cell growth machinery; this is consistent with the surprising finding in human tumours that p53 mutation is often associated with increased, rather than decreased, apoptotic indices (van Slooten et al, 1999). In the context of tumour progression, it is important to note that apoptosis could represent a mechanism of clonal selection for more aggressive cell lineages, rather than simply indicating a benign tumour-suppressive function.

Reductions in mitogenic signal intensity may normally cause cells to arrest and/or differentiate, whereas signal prolongation may trigger differentiation or death (Traverse et al, 1992; Dolmetsch et al, 1997). According to this paradigm, apoptosis may be inducible by forced cell cycle progression in the presence of activated checkpoints (Polet, 1990). Abrogation of p53 function by mutation could thus prevent cells from sensing an abnormally prolonged signal, leading to loss of growth arrest, reduced apoptosis and differentiation, and consequent outgrowth of less differentiated cells. In contrast, ErbB2-dependent impairment of EGFR downregulation both prolongs and intensifies growth factor signalling (Huang et al, 1999), an outcome associated with the increased apoptosis reported here. Such an effect of ErbB2 might be expected to be short-lived, given that selection for apoptotic resistance should be rapid (Balcer-Kubiczek et al, 1995). Acquisition of a p53 defect in this context would cause mutant cells to 'perceive' mitogenic signals as short despite ErbB2-dependent signal prolongation - leading to apoptotic resistance, dedifferentiation and clonal outgrowth.

Human tumours could thus evolve from an interplay between progressive ErbB2 overexpression and acquisition of cell-cycle control defects including, though not necessarily limited to, p53 mutations. We therefore submit that human tissues with cell-cycle control defects (De Cremoux et al, 1999; Prevo et al, 1999) may gain a growth advantage by prolonging and intensifying ambient growth factor signals via ErbB2 upregulation, and that tumour cells overexpressing ErbB2 may in turn clonally select for cell-cycle checkpoint loss (Li et al, 1997).

\section{ACKNOWLEDGEMENTS}

We thank Dr B Vogelstein for kind provision of the p53 dominant negative mutant, and Professor SR Bloom for support. This work was funded by NIH R01 grant 61953 and by Cancer Research UK.

\section{REFERENCES}

Armstrong DK, Kaufmann SH, Ottaviano YL et al (1994) Epidermal growth factor-mediated apoptosis of MDA-MB-468 human breast cancer cells. Cancer Res 54: $5280-5283$

Baker SJ, Markowitz S, Fearon ER, Willson JK, Vogelstein B (1990) Suppression of human colorectal carcinoma cell growth by wild-type p53. Science 249: $912-915$

Balcer-Kubiczek EK, Yin J, Lin K, Harrison GH, Abraham JM, Meltzer S (1995) p53 mutational status and survival of human breast cancer MCF7 cell variants after exposure to $\mathrm{X}$ rays or fission neutrons. Radiat Res 142: $256-262$

Barone MV, Courtneidge SA (1995) Myc but not Fos rescue of PDGF signalling block caused by kinase-inactive Src. Nature 378: 509-512

Baulida J, Kraus MH, Alimandi M, Di Fiore PP, Carpenter G (1996) All erbB receptors other than the epidermal growth factor receptor are endocytosis impaired. J Biol Chem 271: 5251-5257

Ben-Levy R, Paterson HF, Marshall CJ, Yarden Y (1994) A single autophosphorylation site confers oncogenicity to the Neu/ErbB-2 receptor and enables coupling to the MAP kinase pathway. EMBO J 13: $3302-3311$

Berns EM, Foekens JA, Vossen R et al (2000) Complete sequencing of TP53 predicts poor response to systemic therapy of advanced breast cancer. Cancer Res 60: 2155-2162

Bodis S, Siziopikou KP, Schnitt SJ, Harris JR, Fisher DE (1996) Extensive apoptosis in ductal carcinoma in situ of the breast. Cancer 77: 1831-1835

Caleffi M, Teague MW, Jensen RA, Vnencak-Jones CL, Dupont WD, Parl FF (1994) p53 gene mutations and steroid receptor status in breast cancer: clinicopathologic correlations and prognostic assessment. Cancer 73: $2147-2156$

Casey G, Lo-Hsueh M, Lopez ME, Vogelstein B, Stanbridge EJ (1991) Growth suppression of human breast cancer cells by the introduction of a wild-type p53 gene. Oncogene 6: 1791-1797

De Cremoux P, Salomon AV, Liva S et al (1999) p53 mutation as a genetic trait of typical medullary breast carcinoma. J Natl Cancer Inst 91: 641 - 643

Di Fiore PP, Pierce JH, Kraus KH, Segatto O, King CR, Aaronson SA (1987) erbB-2 is a potent oncogene when overexpressed in NIH/3T3 cells. Science 237: $178-181$

Dolmetsch RE, Lewis RS, Goodnow CC, Healy JI (1997) Differential activation of transcription factors induced by calcium response amplitude and duration. Nature 386: $855-857$
Elledge RM, Lock-Lim S, Allred DC, Hilsenbeck SG, Cordner L (1995) p53 mutation and tamoxifen resistance in breast cancer. Clin Cancer Res 1: $1203-1208$

Epstein RJ, Druker BJ, Roberts TM, Stiles CD (1990) Modulation of a 175$\mathrm{kDa}$ c-neu receptor isoform in G8/DHFR cells by serum starvation. J Biol Chem 265: $10746-10751$

Epstein RJ, Druker BJ, Roberts TM, Stiles CD (1992) Synthetic phosphopeptide immunogens yield activation-specific antibodies to the c-erbB-2 receptor. Proc Natl Acad Sci USA 89: 10435- 10439

Evan GI, Wyllie AH, Gilbert CS et al (1992) Induction of apoptosis in fibroblasts by c-myc protein. Cell 69: 119-128

Ferrero-Pous M, Hacene K, Bouchet C, Le Doussal V, Tubiana-Hulin M, Spyratos F (2000) Relationship between c-erbB-2 and other tumor characteristics in breast cancer prognosis. Clin Cancer Res 6: $4745-4754$

Filmus J, Pollak MN, Cailleau R, Buick RN (1985) MDA-468, a human breast cancer cell line with a high number of epidermal growth factor receptors, has an amplified EGF receptor gene and is growth inhibited by EGF. Biochem Biophys Res Comm 128: 898-905

Furuwatari C, Yagi A, Yamagami O et al (1998) A comprehensive system to explore p53 mutations. Am J Clin Pathol 110: $368-373$

Gill GN, Lazar CS (1981) Increased phosphotyrosine content and inhibition of proliferation in EGF-treated A431 cells. Nature 293: 305-307

Gulli LF, Palmer KC, Chen YQ, Reddy KB (1996) Epidermal growth factorinduced apoptosis in A431 cells can be reversed by reducing the tyrosine kinase activity. Cell Growth Differ 7: 173-178

Gulliford T, Huang GC, Ouyang X, Epstein RJ (1997) Reduced ability of transforming growth factor-alpha to induce EGF receptor heterodimerization and downregulation suggests a mechanism of oncogenic synergy with ErbB2. Oncogene 15: 2219-2223

Haldar S, Negrini M, Monne M, Sabbioni S, Croce CM (1994) Down-regulation of bcl-2 by p53 in breast cancer cells. Cancer Res 54: 2095-2097

Harrington EA, Bennett MR, Fanidi A, Evan GI (1994) c-Myc-induced apoptosis in fibroblasts is inhibited by specific cytokines. EMBO J 13: $3286-$ 3295

Harris RA, Hiles ID, Page MJ, O'Hare MJ (1995) The induction of apoptosis in human mammary luminal epithelial cells by expression of activated c$n e u$ and its abrogation by glucocorticoids. Br J Cancer 72: 386-392 
Horak E, Smith K, Bromley L et al (1991) Mutant p53, EGF receptor and cerbB-2 expression in human breast cancer. Oncogene 6: 2277-2284

Huang GC, Ouyang X, Chantry A, Epstein RJ (1999) Overexpression of ErbB2 impairs downregulation of epidermal growth factor receptors via a post-transcriptional mechanism. J Cell Biochem 74: 23-30

Huang GC, Ouyang X, Epstein RJ (1998) Proxy activation of ErbB2 by heterologous ligands suggests a heterotetrameric mechanism of receptor tyrosine kinase interaction. Biochem J 331: 113-119

Kauffmann-Zeh A, Rodriguez-Viciana P, Ulrich E et al (1997) Suppression of c-Myc-induced apoptosis by Ras signalling through PI(3)K and PKB. Nature 385: $544-548$

Kawamoto T, Mendelsohn J, Le A, Sato GH, Lazar CS, Gill GN (1984) Relation of epidermal growth factor receptor concentration to growth of human epidermoid carcinoma A431 cells. J Biol Chem 259: 7761-7766

Kimura A, Ohmichi M, Kurachi H et al (1999) Role of mitogen-activated protein kinase cascade in gonadotropin-releasing hormone-induced growth inhibition of a human ovarian cancer cell line. Cancer Res 59: $5133-5142$

Kita Y, Tseng J, Horan T et al (1996) ErbB receptor activation, cell morphology changes, and apoptosis induced by anti-HER2 monoclonal antibodies. Biochem Biophys Res Comm 226: 59-69

Kuerbitz SJ, Plunkett BS, Walsh WV, Kastan MB (1992) Wild-type p53 is a cell cycle checkpoint determinant following irradiation. Proc Natl Acad Sci USA 89: 7491 - 7495

Lemoine NR, Staddon S, Dickson C, Barnes DM, Gullick WJ (1990) Absence of activating transmembrane mutations in the c-erbB-2 proto-oncogene in human breast cancer. Oncogene 5: 237-239

Li B, Rosen JM, McMenamin-Balano J, Muller WJ, Perkins AS (1997) neu/ ERBB2 cooperates with p53-172H during mammary tumourigenesis in transgenic mice. Mol Cell Biol 17: 3155-3163

Liu E, Thor A, He M, Barcos M, Ljung B, Benz C (1992) The HER2 (c-erbB2) oncogene is frequently amplified in in situ carcinomas of the breast. Oncogene 7: 1027-1032

Marshall CJ (1995) Specificity of receptor tyrosine kinase signaling: transient versus sustained extracellular signal-regulated kinase activation. Cell 80: $179-185$

Marte BM, Graus-Porta D, Jeschke M, Fabbro D, Hynes NE, Taverna D (1995) NDF/heregulin activates MAP kinase and p70/p85 S6 kinase during proliferation or differentiation of mammary epithelial cells. Oncogene 10: $167-175$

Mehta RR, Graves JM, Warso MA, Das Gupta TK (1995) Overexpression of mutant p53 and c-erbB-2 proteins and breast tumour take in mice. $\mathrm{Br} J$ Cancer 72: $1160-1164$

Morrison DK, Kaplan DR, Escobedo JA, Rapp UR, Roberts TM, Williams LT (1989) Direct activation of the serine/threonine kinase activity of raf-1 through tyrosine phosphorylation by the PDGF receptor. Cell 58: 649-657

Mulligan RC, Berg P (1981) Selection for animal cells that express the Escherichia coli gene coding for xanthine-guanine phosphoribosyltransferase. Proc Natl Acad Sci USA 78: 2072-2076

Nikiforov MA, Hagen K, Ossovskaya VS, Connor TM, Lowe SW, Deichman GI, Gudkov AV (1996) p53 modulation of anchorage independent growth and experimental metastasis. Oncogene 13: 1709-1719

Ouyang X, Huang GC, Chantry A, Epstein RJ (1998) Adjacent carboxyterminal tyrosine phosphorylation events identify functionally distinct ErbB2 receptor subsets: implications for molecular diagnostics. Exp Cell Res 241: $467-475$

Ouyang X, Gulliford T, Huang G, Epstein RJ (1999a) Transforming growth factor-alpha short-circuits downregulation of the epidermal growth factor receptor. J Cell Physiol 179: 52-57

Ouyang X, Gulliford T, Doherty A, Huang GC, Epstein RJ (1999b) Detection of ErbB2 oversignalling in a majority of breast cancers with phosphorylation-state-specific antibodies. Lancet 353: 1591-1592

Ouyang X, Gulliford T, Zhang H, Smith G, Huang GC, Epstein RJ (2001) Association of ErbB2 Ser-1113 phosphorylation with epidermal growth factor receptor co-expression and poor prognosis in human breast cancer. Mol Cell Biochem 218: 47-54
Packham G, Porter CW, Cleveland JL (1996) c-Myc induces apoptosis and cell cycle progression by separable, yet overlapping, pathways. Oncogene 13: $461-469$

Pinto AE, Andre S, Pereira T, Nobrega S, Soares J (2001) c-ErbB-2 oncoprotein overexpression identifies a subgroup of estrogen receptor positive $(\mathrm{ER}+)$ breast cancer patients with poor prognosis. Ann Oncol 12: 525-533

Polet H (1990) Epidermal growth factor stimulates DNA synthesis while inhibiting cell multiplication of A431 carcinoma cells. Exp Cell Res 186: 390 393

Prevo LJ, Sanchez CA, Galipeau PC, Reid BJ (1999) p53-mutant clones and field defects in Barrett's esophagus. Cancer Res 59: 4784-4787

Pumiglia KM, Decker SJ (1997) Cell cycle arrest mediated by the MEK/mitogen-activated protein kinase pathway. Proc Natl Acad Sci USA 94: 448 - 452

Sainsbury JRC, Sherbet GV, Farndon JR, Harris AL (1985) Epidermal growth factor receptors and oestrogen receptors in human breast cancer. Lancet i: $364-366$

Slamon DJ, Godolphin W, Jones LA et al (1989) Studies of the HER-2/neu proto-oncogene in human breast and ovarian cancer. Science 244: $707-$ 712

Slichenmeyer WJ, Nelson WG, Slebos RJ, Kastan MB (1993) Loss of a p53associated G1 checkpoint does not decrease cell survival following DNA damage. Cancer Res 53: 4164-4168

Sorkin A, Di Fiore PP, Carpenter G (1993) The carboxyl terminus of epidermal growth factor receptor/erbB-2 chimerae is internalization impaired. Oncogene 8: $3021-3028$

Tagliabue E, Centis F, Campiglio M et al (1991) Selection of monoclonal antibodies which induce internalization and phosphorylation of $\mathrm{p} 185^{\mathrm{HER} 2}$ and growth inhibition of cells with HER2/neu gene amplification. Int J Cancer 47: $933-937$

Towbin H, Staehelin T, Gordon J (1979) Electrophoretic transfer of proteins from polyacrylamide gels to nitrocellulose sheets: procedure and some applications. Proc Natl Acad Sci USA 76: $4350-4354$

Traverse S, Gomez N, Paterson H, Marshall C, Cohen P (1992) Sustained activation of the mitogen-activated protein (MAP) kinase cascade may be required for differentiation of PC12 cells. Biochem J 288: 351 - 355

Tsuda H, Sakamaki C, Tsugane S, Fukutomi T, Hirohashi S (1998) A prospective study of the significance of gene and chromosome alterations as prognostic indicators of breast cancer patients with lymph node metastases. Breast Cancer Res Treat 48: $21-32$

Tyner SD, Choi J, Laucirica R, Ford RJ, Donehower LA (1999) Increased tumor cell proliferation in murine tumors with decreasing dosage of wild-type p53. Mol Carcinogenesis 24: 197-208

van Slooten HJ, van de Vijver MJ, Borresen AL et al (1999) Mutations in exons 5-8 of the p53 gene, independent of their type and location, are associated with increased apoptosis and mitosis in invasive breast carcinoma. $J$ Pathol 189: $504-513$

Vasey PA, Jones NA, Jenkins S, Dive C, Brown R (1996) Cisplatin, camptothecin, and taxol sensitivities of cells with p53-associated multidrug resistance. Mol Pharmacol 50: $1536-1540$

Woods D, Parry D, Cherwinski H, Bosch E, Lees E, McMahon M (1997) Rafinduced proliferation or cell cycle arrest is determined by the level of Raf activity with arrest mediated by p21 ${ }^{\mathrm{Cip} 1}$. Mol Cell Biol 17: 5598-5611

Wright M, Grim J, Deshane J, Kim M, Strong TV, Siegal GP, Curiel DT (1997) An intracellular anti-erbB-2 single-chain antibody is specifically cytotoxic to human breast carcinoma cells overexpressing erbB-2. Gene Ther 4: $317-322$

Wyllie FS, Haughton MF, Blaydes JP, Schlumberger M, Wynford-Thomas D (1995) Evasion of p53-mediated growth control occurs by three alternative mechanisms in transformed thyroid epithelial cells. Oncogene 10: 49-59

Yin Y, Tainsky MA, Bischoff FZ, Strong LC, Wahl GM (1992) Wild-type p53 restores cell cycle control and inhibits gene amplification in cells with mutant p53 alleles. Cell 70: $937-948$

Zhang W, Guo XY, Hu GY, Liu WB, Shay JW, Deisseroth AB (1994) A temperature-sensitive mutant of human p53. EMBO J 13: 2535-2544 